\title{
The implementation of the New Urban Agenda. Our ongoing efforts after almost two years from the Habitat III conference
}

\author{
Luisa Bravo \\ City Space Architecture, Italy \\ luisa.bravo@cityspacearchitecture.org
}

When City Space Architecture was selected to be part of Habitat III, the United Nations conference on Housing and Sustainable Urban Development, held in Quito in 2016,1 I realized that our efforts to promote public space culture and to give a contribution on the ongoing global discourse around public space were clearly visible and well understood. At the same it was clear to me that being part of the Habitat III conference was our once-in-a-lifetime opportunity to start an ambitious and difficult path that could potentially have lead to remarkable achievements.

City Space Architecture is a non-profit cultural association based in Bologna, Italy. Its strength is based on the ideals that are the pillars of its foundation: trust, solidarity and cooperation. All our affiliated members are volunteering their time because they are willing to give and I myself, as Founder and current President-elect, too. Our members come from academia, industry, governmental institutions and NGOs but we also engage students since our mission is mostly focused on quality education related to public space culture of young generations of future leaders. We always engage students in our projects, events and activities since we know they will carry the burden to build a more sustainable urban future for all, they will serve communities and will be asked to work as decision makers and influential advisors. We want them to be proud, committed and responsible ambassadors of public space culture, we want them to be servants of the public good.

Nowadays we are facing an unprecedented situation: the 'urban' is complex, like never before, and a great suffer comes from the humanity as a whole. The rise of poverty has generated conflicts and political instability in many countries. Equity, social justice and democracy are challenged by private interests and public space is seriously at risk. The New Urban Agenda adopted at the Habitat III conference and the related Sustainable Development Goals and their targets, with particular reference to SDG II.72, recognize that public space is a key element for sustainable urban development. I strongly and passionately believe that

\footnotetext{
' At the Habitat III conference City Space Architecture organized and I coordinated the networking event 'Stand up for Public Space!' and a talk at the Urban Library for the launch of the first issue of The Journal of Public Space. Both events were very well attended. A report of both events is published on the issue Vol. 2, n. I (2017) of the journal. More on Habitat III here: http://habitat3.org/.

${ }^{2}$ According to the global indicator framework, the target retlated to SDG II.7 is: 'By 2030, provide universal access to safe, inclusive and accessible, green and public spaces, in particular for women and children, older persons and persons with disabilities' - https://sustainabledevelopment.un.org/sdgII
} 
public space is a fundamental human right, it is so precious but also so fragile that needs to be protected and preserved, if we really want to build cities for all, leaving no one behind. In 2017 I was engaged in two major UN events: I was nominated to attend the $26^{\text {th }} \mathrm{UN}$ Habitat Governing Council in Nairobi and then granted an ad hoc-accreditation by Member States with a letter of invitation signed by the former UN-Habitat Executive Director Dr. Joan Clos; I was then selected by a Committee appointed by UN NGLS Non-Governmental Liaison Services to attend the High Level Meeting on the New Urban Agenda in New York. In 2018 City Space Architecture was selected to organize a networking event, that I coordinated, at the 9th World Urban Forum (WUF9) ${ }^{3}$ in Kuala Lumpur and was also selected as exhibitor (the only Italian exhibitor) together with 200 exhibitors from 50 countries. WUF9 was the first session to focus on the implementation of the New Urban Agenda adopted in Habitat III, under the theme 'Cities 2030: Cities for All' and attracted more than 22,000 participants from 165 countries. At the close of the meeting, WUF9 launched the Kuala Lumpur Declaration on Cities 2030, which calls for accelerating NUA implementation and maintaining UN-Habitat as the UN focal point for follow-up and review of the NUA. Since the Habitat III conference in Quito, and afterwards in Nairobi, New York and Kuala Lumpur, I had the chance to meet and share knowledge with global stakeholders, to establish connections with many institutions that are promoting projects and programmes addressing global challenges, to be observer and speaker in relevant roundtable discussions, and I learned more about public space, how it is improved, appropriated and lived but also undermined, neglected and abused. More than ever, we need to be committed and continue our work on promoting public space culture and spread awareness on the importance of public space in cities.

This issue (Vol. 3, n.I, 20I8) of The Journal of Public Space includes a section with reports from WUF9 from major stakeholders addressing challenges related to public space, that City Space Architecture supported as partners during meetings and events at WUF9: KTH Royal Institute of Technology and Ax:son Johnson Foundation (Sweden), the University of Auckland (New Zealand), UN General Assembly of Partners Older Persons (USA), IHC Global (USA) and Urban Synergies Group (Australia).

City Space Architecture is currently organizing a symposium which will take place at the Venice Architecture Biennale on September 22, in the framework of the educational programme 'Biennale Session'. In Venice several insttitutions will convene and continue the discussion on public space, such as: KTH Royal Institute of Technology (Sweden), TU Vienna (Austria), Stanford Human Cities Initiative (USA), Keio University (Japan), Lodz University of Technology (Poland), The Graudate Center of the City University of New York (USA) and others are currently confirming their attendance. Some representatives from the UNHabitat's Global Public Space Programme will also attend. It's time to take action and we need to work all together.

\section{To cite this article:}

Bravo, L. (2018). The implementation of the New Urban Agenda. Our ongoing efforts after almost two years from the Habitat III conference. The Journal of Public Space, 3(I), I-2, DOI:

$10.5204 /$ jps.v3il.314

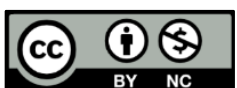

This work is licensed under a Creative Commons Attribution - Non Commercial 4.0 International License https://creativecommons.org/licenses/by-nc/4.0/

\footnotetext{
${ }^{3}$ More on WUF9 here: http://wuf9.org/ and on events on public space at WUF9 here: http://wuf9.org/programme/thematic-itineraries/public-space/
}

2 | The Journal of Public Space, 3(I), 20I8 | ISSN 2206-9658

City Space Architecture / Queensland University of Technology / UN-Habitat 